\title{
U.S. Geological Survey Geohydrologic Studies and Monitoring at the Idaho National Laboratory, Southeastern Idaho
}

\section{Background}

The U.S. Geological Survey (USGS) geohydrologic studies and monitoring at the Idaho National Laboratory (INL) (fig. 1) is an ongoing, long-term program. This program, which began in 1949, includes hydrologic monitoring networks and investigative studies that describe the effects of waste disposal on water contained in the eastern Snake River Plain (ESRP) aquifer and the availability of water for long-term consumptive and industrial use. Interpretive reports documenting study findings are available to the U.S. Department of Energy (DOE) and its contractors; other Federal, State, and local agencies; private firms; and the public at https://id.water.usgs.gov/INL/Pubs/index. $\mathrm{html}$. Information contained within these reports is crucial to the management and use of the aquifer by the INL and the State of Idaho. USGS geohydrologic studies and monitoring are done in cooperation with the DOE Idaho Operations Office.

\section{Geohydrologic Setting}

The INL is in the west-central part of the eastern Snake River Plain (ESRP). The ESRP is a northeast-trending structural basin about $200 \mathrm{mi}$ long and 50-70 mi wide (fig. 1). The basin, bounded by faults on the northwest and by downwarping and faulting on the southeast, has been filled with basaltic lava flows interbedded with terrestrial sediments. The basaltic rocks and sedimentary deposits combine to form the ESRP aquifer, which is the primary source of groundwater for the ESRP.

The ESRP aquifer is one of the most productive aquifers in the United States (U.S. Geological Survey, 1985, p. 193). Groundwater generally moves from northeast to southwest and discharges to springs along the Snake River downstream of Twin Falls, Idaho, about $100 \mathrm{mi}$
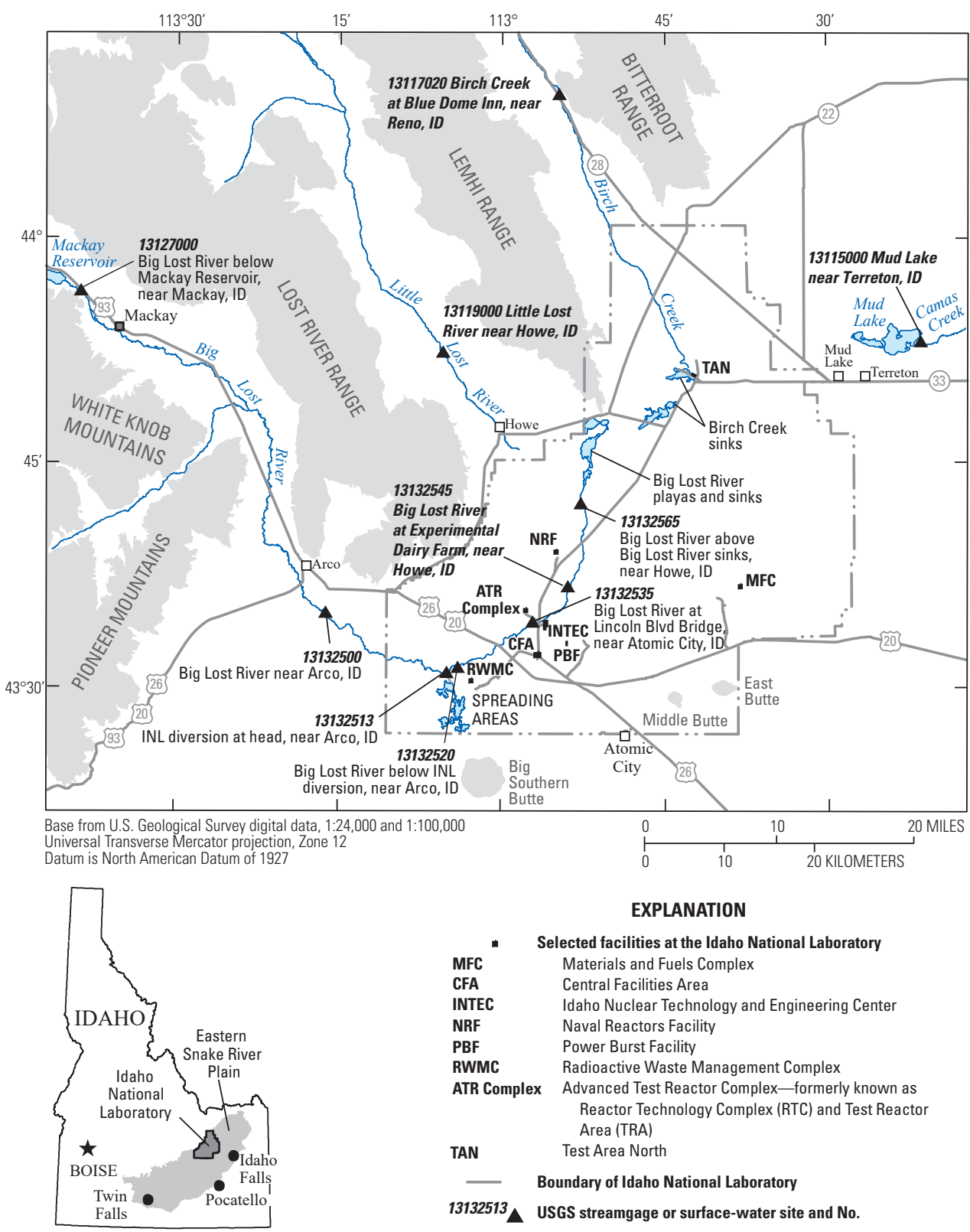

Figure 1. Locations of facilities, selected U.S. Geological Survey streamgages, and other features, Idaho National Laboratory, southeastern Idaho. 
southwest of the INL (fig. 1). The ESRP aquifer is recharged primarily from infiltration of applied irrigation water, infiltration of streamflow, groundwater inflow from adjoining mountain drainage basins, and infiltration of precipitation (Ackerman and others, 2006). Recharge to the ESRP aquifer at the INL is influenced by local surface drainage. The Big Lost River drains more than $1,390 \mathrm{mi}^{2}$ of mountainous area that includes parts of the Lost River and Pioneer Mountains west of the INL (fig. 1). The average streamflow in the Big Lost River downstream of the Mackay Reservoir for complete water years (1905-2015) was 216,700 acre-ft/ yr (Bartholomay and others, 2017, fig. 8). Flow in the Big Lost River infiltrates to the ESRP aquifer along its channel and at sinks and playas at the river's terminus in the Big Lost River sinks. Since 1965, the DOE has diverted excess runoff from the Big Lost River that reaches the INL to spreading areas in the southwestern part of the INL, to prevent flooding at site facilities.

Discharge from the ESRP aquifer is primarily by pumping for irrigation and flow from springs to the Snake River (Mann and Knobel, 1990). Spring discharge fluctuates as a result of changes in water use, irrigation practices and precipitation (Kjelstrom, 1992). For water year 2015, 3.45 million acre-ft/yr of groundwater were discharged from springs along the Snake River downstream of Twin Falls (Bartholomay and others, 2017).

At the INL, depth to water in wells completed in the ESRP aquifer ranges from about $225 \mathrm{ft}$ below land surface (BLS) in the northern part of the INL to more than $900 \mathrm{ft}$ BLS in the southeastern part of the INL (Bartholomay and others, 2017). A significant proportion of the groundwater moves through the upper 200-800 ft of basaltic rock (Mann, 1986, p. 21). Ackerman (1991, p. 30) and Bartholomay and others (1997, table 3 ) reported transmissivity values for basalt in the upper part of the aquifer ranging from 1.1 to $760,000 \mathrm{ft}^{2} / \mathrm{d}$. The hydraulic gradient at the INL ranges from 2 to $10 \mathrm{ft} / \mathrm{mi}$, with an average of $4 \mathrm{ft} / \mathrm{mi}$ (Bartholomay and others, 2017, fig. 9). Horizontal flow velocities of
2-26 ft/d have been calculated based on the movement of various constituents in different areas of the aquifer at and near the INL (Robertson and others, 1974; Mann and Beasley, 1994; Cecil and others, 2000; Plummer and others, 2000; Busenberg and others, 2001). These flow rates equate to a travel time of about 50-700 years for water beneath the INL to travel to springs that discharge at the terminus of the ESRP groundwater- flow system near Twin Falls.

\section{Geohydrologic Studies}

\section{Geologic Framework}

The solid part of the ESRP aquifer beneath the INL consists of olivine tholeiite basalt flows, interlayered with thin windborne and water-borne sediment. Basalts and sediments were deposited in a subsiding basin during the past 10 million years. At the INL, subsidence, episodic emplacement of basalt flows, and sediment deposition resulted in a succession of basalt flows and sediment layers that composes the ESRP aquifer, and the aquifer ranges in total thickness from about 445 to 1,200 ft (Ackerman and others, 2006, p. 25). Groundwater movement through the sediment is affected by the amount and type of sediment that is present; fine-grained sediment generally impedes groundwater movement, and coarse-grained sediment may enhance groundwater movement. Groundwater movement through basalt is affected by the size and character of individual lava flows, as a series of thin flows allows water movement more readily than a thick, massive flow. The fractures at the tops, sides, and bases of basalt flows form interconnected networks (interflow zones) where most groundwater movement occurs. Sediment layers and dense, thick basalt flows can significantly impede groundwater movement.

In past years, borehole geophysical data (natural gamma logs) from 333 wells and lithological data from numerous cores were used to create a two-dimensional geologic framework for a variety of facility-scale and INL-scale hydrologic investigations. The stratigraphic information was used in 2006 to develop a conceptual geologic framework for the USGS groundwater-flow and contaminanttransport models (Ackerman and others, 2006). To improve the geologic framework used in the conceptual and numerical models, the USGS has been performing additional core drilling, rock core testing, and mapping and sampling of surface flow vents to trace the vents from the surface to the subsurface. Threedimensional modeling that incorporates paleomagnetic measurements, age dates, and other data from recently cored wells is being used to better define the stratigraphy and hydrogeologic properties of the aquifer beneath the INL; this ongoing work will be used to redefine the USGS conceptual model of groundwater flow and contaminant transport.

\section{Geochemical Modeling}

The chemical and radiochemical constituents in groundwater at the INL are derived from natural and anthropogenic processes involving reactions between the solid, liquid, and gaseous phases. To define these reactions and subsequent effect on contaminant transport, it is necessary to understand the natural geochemistry of the system, as well as the geochemistry and geochemical evolution of source water to the aquifer at the INL. Source water includes infiltrating surface water and irrigation return flow, groundwater from tributary valleys, groundwater from the ESRP aquifer northeast of the INL, industrial-waste discharge, and geothermal water. The water from each of these sources has a chemistry related to the unique water-rock interactions and other processes that have taken place throughout its travel history. When these waters mix, the chemistry of water in the ESRP aquifer at the INL is affected. Several zones of mixing have been identified: Birch Creek Playa area, Little Lost River/Big Lost River Playa area, Big Lost River Channel/Big Lost River spreading area, and the southeastern INL throughflow area. As recharge waters mix with groundwater in these areas, the thermodynamic characteristics of the 
system change and cause reactions that further change the natural chemistry of the system. As this water moves in the ESRP aquifer at and downgradient of the INL, the water continues to be affected by the natural reactions of groundwater and the solid-phase matrix of the aquifer, by the characteristics of the groundwater flow system, and by the effects of waste disposal. Work to understand the chemistry of groundwater and the transport of wastewater in the system is ongoing.

\section{Groundwater-Flow and Contaminant Transport Models}

A thorough understanding of the movement and fate of contaminants in the ESRP aquifer is needed by the DOE and the State of Idaho to minimize health and safety risks and to effectively plan for remediation if necessary. To achieve these goals, the groundwater-flow and contaminant-transport models are being used to determine the long-term risks associated with contaminants that are present in the aquifer today or that might be present in the future from additional slow releases of residual contamination.

Numerical models derived from the conceptual model (Ackerman and others, 2006) provide quantitative estimates of hydraulic properties and head, flow paths, travel times, and contaminantplume migrations throughout the modeled aquifer. Two types of three-dimensional flow models have been developed: (1) a steady-state model that assumes inflows into the aquifer equal outflows and assumes no time-dependent changes in aquifer storage or changes in the direction and velocity of water movement; and (2) a transient model that allows water inflows and outflows to vary in response to short- and long-term changes in climate or water-use patterns resulting in an increase or decrease in aquifer storage and changes in the direction and velocity of water movement. A report describing these flow models (Ackerman and others, 2010) was published in 2010. Additional data are being used to revise these flow models and the revised models will be used to determine the risk of groundwater contamination associated with site selection and operation of future INL research facilities.

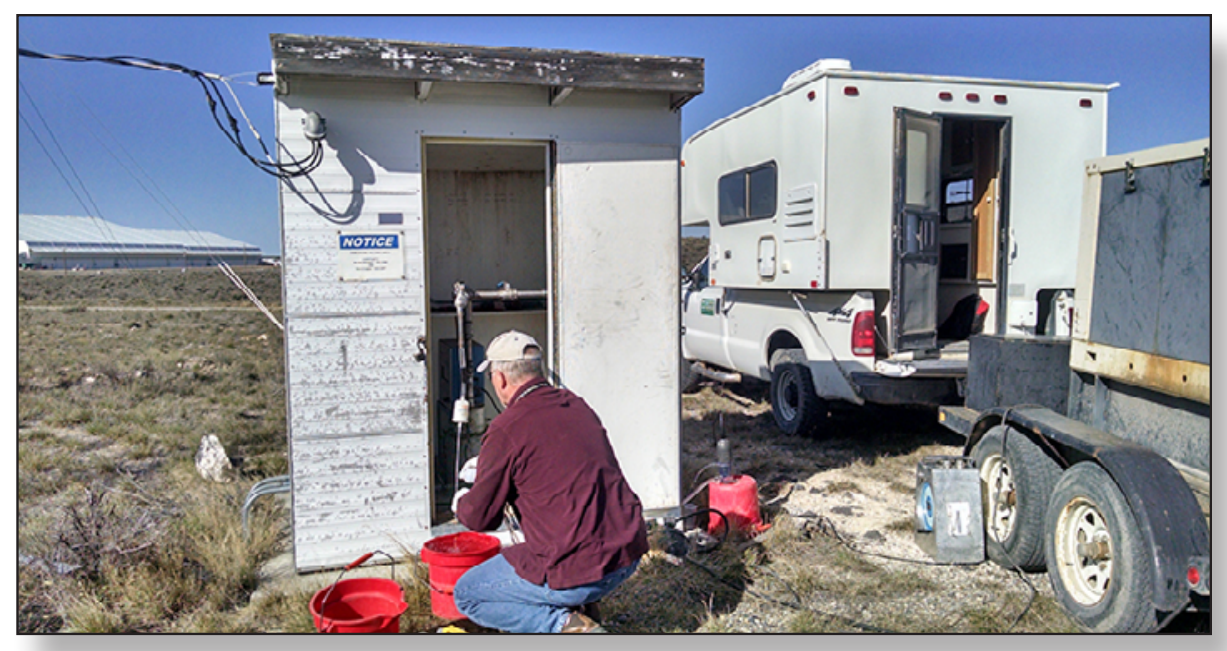

Figure 2. USGS hydrologist collecting a water sample from a well at the Idaho National Laboratory, southeastern Idaho.

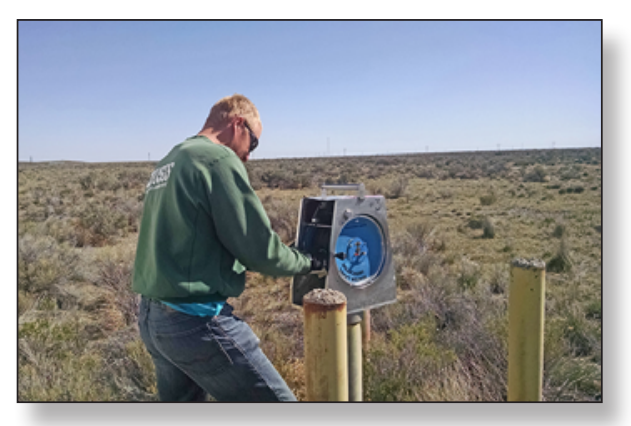

Figure 3. USGS hydrologic technician collecting a water-level measurement from a well at the Idaho National Laboratory, southeastern Idaho.

\section{Water-Quality and Water-Level Monitoring}

Since the inception of the monitoring program in 1949, water-quality samples (fig. 2) and water-level measurements (fig. 3) have been collected from a network of more than 200 wells. Samples and measurements have been collected primarily from wells open to the aquifer through their entire depth below the water table. This type of construction is good for maximum water-production rates, for identifying the time of arrival of contaminant plumes, and for delineating the horizontal extent of contaminants. As of 2017, water samples were being collected from 143 wells and analyzed for some combination of concentrations of tritium, strontium-90, cesium-137, plutonium-238, plutonium-239 and -240 (undivided), americium-241, gross alphaand beta-particle radioactivity; chromium, sodium, chloride, and sulfate; nutrients including nitrite plus nitrate (as nitrogen
$[\mathrm{N}]$ ), nitrite (as N), orthophosphate (as $\mathrm{P}$ ), and ammonia (as $\mathrm{N}$ ); volatile organic compounds (VOCs); and measurements of specific conductance, $\mathrm{pH}$, and temperature. As of 2017, water levels were being collected from 213 wells on either a monthly, quarterly, semi-annual, or annual basis. Eight of the wells record continuous measurement information. Data collected from hydrologic monitoring activities are added to the USGS National Water Information System database (https:// water.usgs.gov/nwis/).

\section{Streamflow Monitoring}

From 1984 through 2009, the USGS Idaho Water Science Center's Idaho Falls Field Office operated a hydrologic network in the Big Lost River Basin that consisted of eight streamgages, six crest-stage gages, and one lakestage gage. During fiscal year 2009, the USGS and the DOE decided to reduce the number of sites in the network to only seven streamgages (figs. 1 and 4).

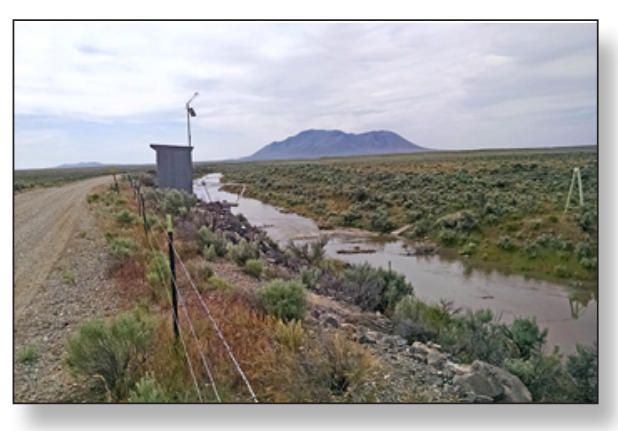

Figure 4. USGS streamgage (site No. 13132513) that measures the amount of flow into the Idaho National Laboratory spreading areas. 
Data Collection Platforms with satellite telemetry are installed at all seven of the streamgages to provide real-time hydrologic information. Data have been collected continuously at two of the three most upstream gages since the early 1900s; data collection at the third upstream gage started in the 1940s. The current hydrologic network in the Big Lost River Basin is used to determine annual snowmelt runoff, to calculate seepage losses from the main channel and diversions, to estimate infiltration in ponded areas, and to aid in flood-control studies. In addition, telemetry in the basin lets the INL facilities immediately assess storage and flow conditions in the Big Lost River. Hydrologic data for the network are available at https:/water.usgs.gov/nwis/. In addition to streamflow measurements on the Big Lost River, the USGS INL Project office routinely collects streamflow water-quality samples annually at four sites along the Big Lost River, and one site each on the Little Lost River, Birch Creek, and Mud Lake to determine baseline water chemistry that contributes recharge to the ESRP aquifer (fig. 1).

\section{References Cited}

Ackerman, D.J., 1991, Transmissivity of the Snake River Plain aquifer at the Idaho National Engineering Laboratory, Idaho: U.S. Geological Survey Water-Resources Investigations Report 91-4058 (DOE/ID-22097), 35 p., http://pubs.er.usgs.gov/ publication/wri914058.

Ackerman, D.J., Rattray, G.W., Rousseau, J.P., Davis, L.C., and Orr, B.R., 2006, A conceptual model of ground-water flow in the eastern Snake River Plan aquifer at the Idaho National Laboratory and vicinity with implications for contaminant transport: U.S. Geological Survey Scientific Investigations Report 2006-5122 (DOE/ID-22198), 62 p., http://pubs.er.usgs. gov/publication/sir20065122.

Ackerman, D.J., Rousseau, J.P., Rattray, G.W., and Fisher, J.C., 2010, Steady-state and transient models of groundwater flow and advective transport, eastern Snake River Plain aquifer, Idaho National Laboratory and vicinity, Idaho: U.S. Geological Survey Scientific Investigations Report 2010-5123 (DOE/ ID-22209), 220 p., http://pubs.usgs.gov/sir/2010/5123/.

Bartholomay, R.C., Maimer, N.V., Rattray, G.W., and Fisher, J.C., 2017, An update of hydrologic conditions and distribution of selected constituents in water, eastern Snake River Plain aquifer and perched groundwater zones, Idaho National Laboratory, Idaho, emphasis 2012-15: U.S. Geological Survey Scientific Investigations Report 2017-5021 (DOE/ID-22242), 87 p., https://doi.org/10.3133/sir20175021.

Bartholomay, R.C., Tucker, B.J., Ackerman, D.J., and Liszewski, M.J., 1997, Hydrologic conditions and distribution of selected radiochemical and chemical constituents in water, Snake River Plain aquifer, Idaho National Engineering Laboratory, Idaho, 1992 through 1995: U.S. Geological Survey Water-Resources Investigations Report 97-4086 (DOE/ID-22137), 57 p., http:// pubs.er.usgs.gov/usgspubs/wri/wri974086.

Busenberg, Eurybiades, Plummer, L.N., and Bartholomay, R.C., 2001, Estimated age and source of the young fraction of ground water at the Idaho National Engineering and Environmental Laboratory: U.S. Geological Survey Water-Resources Investigations Report 2001-4265 (DOE/ID-22177), 144 p., http://pubs.er.usgs.gov/publication/wri014265.
Cecil, L.D., Welhan, J.A., Green, J.R., Frape, S.K., and Sudicky, E.R., 2000, Use of chlorine-36 to determine regional-scale aquifer dispersivity, eastern Snake River Plain aquifer, Idaho/ USA: Nuclear Instruments and Methods in Physics Research, section B, v. 172, nos. 1-4, p. 679-687.

Kjelstrom, L.C., 1992, Assessment of spring discharge to the Snake River, Milner Dam to King Hill, Idaho: Water Fact Sheet, U.S. Geological Survey Open-File Report 92-142, 2 p.

Mann, L.J., 1986, Hydraulic properties of rock units and chemical quality of water for INEL-1-A 10,365-foot deep test hole drilled at the Idaho National Engineering Laboratory, Idaho: U.S. Geological Survey Water-Resources Investigations Report 86-4020 (DOE/ID-22070), 23 p., http://pubs.er.usgs.gov/publication/wri864020.

Mann, L.J., and Beasley, T.M., 1994, Iodine-129 in the Snake River Plain aquifer at and near the Idaho National Engineering Laboratory, Idaho, 1990-1991: U.S. Geological Survey Water-Resources Investigations Report 94-4053 (DOE/ID-22115), 27 p., http://pubs.er.usgs.gov/publication/ wri944053.

Mann, L.J., and Knobel, L.L., 1990, Radionuclides, metals, and organic compounds in water, eastern part of A \& B Irrigation District, Minidoka County, Idaho: U.S. Geological Survey Open-File Report 90-191 (DOE/ID-22087), 36 p.

Plummer, L.N., Rupert, M.G., Busenberg, Eurybiades, and Schlosser, P., 2000, Age of irrigation water in ground water from the eastern Snake River Plain aquifer, south-central Idaho: Ground Water, v. 38, no. 2, p. 264-283.

Robertson, J.B., Schoen, Robert, and Barraclough, J.T., 1974, The influence of liquid waste disposal on the geochemistry of water at the National Reactor Testing Station, Idaho, 19521970: U.S. Geological Survey Open-File Report 73-238 (IDO-22053), 231 p., http://pubs.er.usgs.gov/publication/ ofr73238.

U.S. Geological Survey, 1985, National water summary, 1984 Hydrologic events, selected water-quality trends, and groundwater resources: U.S. Geological Survey Water-Supply Paper 2275, 467 p. [Also available at http://pubs.er.usgs.gov/ publication/wsp2275.]

Author: Roy C. Bartholomay

For information contact:

USGS INL Project Office

1955 N. Fremont

Idaho Falls, Idaho 83415

https://id.water.usgs.gov

All photographs by U.S. Geological Survey unless otherwise noted.

Publishing support provided by the

U.S. Geological Survey

Science Publishing Network

Tacoma Publishing Service Center 